\title{
Loyalty As Affecting Mediator Of Service Quality And Customer Satisfaction Towards Competitive Advantage
}

\author{
Mohammad Hamim Sultoni ${ }^{1}$, Sudarmiatin ${ }^{2}$ \\ ${ }^{1}$ Department of Sharia Banking, Faculty of Economics and Islamic Business, Institut \\ Agama Islam Negeri Madura, Jl. Panglegur KM 04, Pamekasan, 69371, Indonesia \\ 1,2 Doctoral of Management Science, Faculty of Economics, Universitas Negeri \\ Malang, Jl. Semarang No 5, Malang, 65145, Indonesia \\ E-mail: mohammad.hamim.2004139@students.um.ac.id
}

A R T I C L I I F O A B S R A C T

Article history:

Received: 01 Apr 2021

Revised: 15 Apr 2021

Accepted: 30 Apr 2021

Keywords:

Customer loyalty;

Customer satisfaction;

Service quality;

Competitive advantage.

\begin{abstract}
When preparing an effective marketing strategy, a bank must consider its competitors as well as its customers. Establishing a mutual relationship with customers requires a better means of satisfying customer needs than the competitors. Micro, Small, and Medium-sized Enterprises (MSMEs) should always analyze their competitors and develop marketing strategies that effectively give the company a good position compared to the competitors and provide a competitive advantage as strong as possible. This research was conducted using a quantitative method. The design was categorized as causal relationship research. The data were then analyzed using the path analysis. Findings of the research showed that customer satisfaction, service quality, and customer loyalty affected the competitive advantage of Sentra Batik Pamekasan. The effect of customer loyalty on the competitive advantage could be observed from the number of Sentra Batik Pamekasan's customers who decided not to move to other financial institutions (banks). When the company could give better service quality, the customer loyalty and the competitive advantage among financial institutions would get higher.
\end{abstract}

\section{Introduction}

Basically, all companies have a strategy. However, the companies usually do not realize that plans and activities which they are running constitute as one of the strategies to compete. Forms of the strategies can vary from industry to industry, from company to company, and from situation to situation. Thus, every company might have different strategies from its competitors ${ }^{1}$.

In the recent decade, stiff competition undeniably occurs in the batik industry. Hence, corporation behavior towards customers should always be taken into account. The competition does not only occur in a large number of batik, but also in the efforts to find customers and retain the existing ones ${ }^{2}$. Thus, the perceived performance of the company's product is highly required. Perceived performance is based on the customer's knowledge, belief, and evaluation of brand, product performance, image, and services. Once the customers perceive those aspects as satisfactory, customer loyalty will be formed which is indicated by the repeated use of the product for the long term ${ }^{3}$.

${ }^{1}$ Budi Gautama Siregar, Strategi Bersaing Dalam Meningkatkan Jumlah Konsumen PT. Bank Sumut Cabang Syariah Padang Sidimpuan, FITRAH Jurnal Kajian Ilmu-Ilmu Keislaman, Vol.03 No.1 June 2017, Lecturer of Faculty of Islamic Economic and Business, IAIN Padang sidimpuan, p. 40

${ }^{2}$ Aulia Danibrata, Pengaruh Strategi Bersaing Dengan Menggunakan Kualitas dan Kerelasian Pelanggan Terhadap Loyalitas Pelanggan Pada Industri Perbankan, Jurnal Bisnis dan Akuntansi, Vol.15, No.1, June 2013, p. 90

${ }^{3}$ Aulia Danibrata, Pengaruh Strategi Bersaing Dengan Menggunakan Kualitas dan Kerelasian Pelanggan Terhadap Loyalitas Pelanggan Pada Industri Perbankan, p. 85 
Service activities refer to activities that are expected by the Micro, Small, and Medium-sized Enterprises (MSMEs) to increase income and customer confidence. Some MSMEs strive to improve information and technology in order to provide a satisfying service to their customers. The satisfying service includes a fast and accurate service. Undoubtedly, every customer expects fast and accurate service. Hence, all MSMEs are racing to create innovation that can enhance the quality of their services ${ }^{4}$.

When preparing an effective marketing strategy, corporations must consider their competitors and customers. Establishing a mutual relationship requires a better means of satisfying customer's needs than the competitors. The MSMEs should always analyze their competitors and develop marketing strategies that effectively give the company a good position compared to the competitors and provide a competitive advantage as strong as possible ${ }^{5}$.

\section{Research Method}

This research used a quantitative approach. As the name suggests, this sort of research uses numerical data and statistical data analysis. The research method referred to the causal research which denoted a causal relationship ${ }^{6}$. To analyze the data, the researcher used path analysis because there was affecting mediation between independent and dependent variables. Three variables were used in this research, namely:

a. The independent variable, a variable that causes the dependent variable to occur/affect. In this context, the independent variables were Customer Satisfaction and Service Quality $\left(\mathrm{X}_{1}\right.$ and $\left.\mathrm{X}_{2}\right)$.

b. The dependent variable, a variable whose value is affected by the independent variable. In this research, the dependent variable is referred to as Competitive Advantage (Y).

c. Intervening variable, a variable that acts as a mediator between independent and dependent variables. In this research, the intervening variable was customer loyalty (Z). Customer loyalty served as a mediator to identify the relationship or effect of customer satisfaction and service quality $\left(\mathrm{X}_{1}\right.$ and $\left.\mathrm{X}_{2}\right)$ towards competitive advantage (Y).

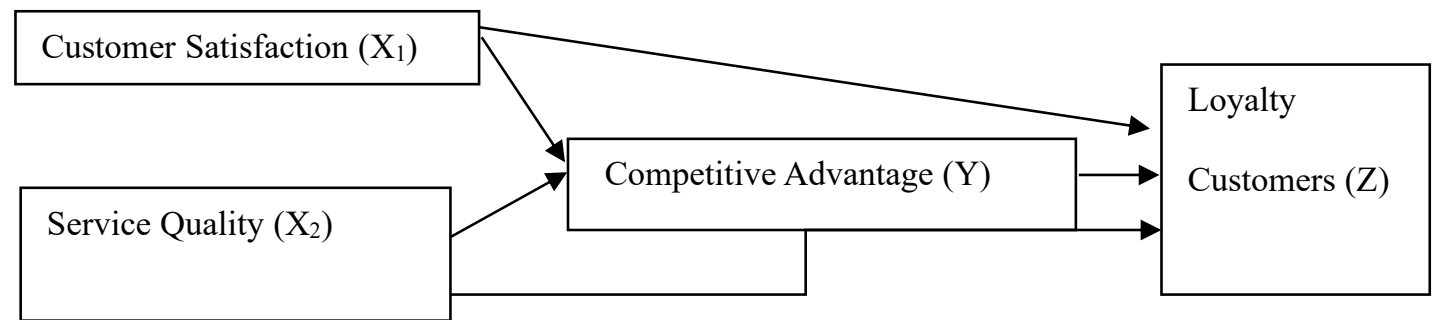

Fig 1.The Design of Operational Variables

\section{Discussion and Findings}

Based on the research findings, customer satisfaction $\left(\mathrm{X}_{1}\right)$ had a significant direct effect on competitive advantage $(\mathrm{Y})$, with a significance value of $0.004<0.05$. Thus, it can be concluded that there was a significant direct effect of customer satisfaction $\left(\mathrm{X}_{1}\right)$ on competitive advantage $(\mathrm{Y})$ in which the $\mathrm{R}$ Square reached 0.826 . The summary table showed that customer satisfaction significantly affected competitive advantage by $82.6 \%$. meanwhile, the rest $(17.4 \%)$ referred to other factors that were not included in this research. It means that customer satisfaction had a significant positive effect on competitive advantage in the Sentra Batik Pamekasan. Based on the findings, customer satisfaction $\left(\mathrm{X}_{1}\right)$ had a significant direct effect on customer loyalty $(\mathrm{Z})$, with a significance value of $0.499<0.05$. Thus, it can be concluded that there was a significant direct effect of customer satisfaction $\left(\mathrm{X}_{1}\right)$ on customer loyalty $(\mathrm{Z})$ in which the R Square reached 0.616 . The summary table showed that customer satisfaction significantly affected customer loyalty by $61.6 \% \%$. Meanwhile, the rest $(38.4 \%)$ referred to other factors that were not included in this research. It means that customer satisfaction has a significant positive effect on customer loyalty in the Sentra Batik Pamekasan.

The findings also reported that service quality $\left(\mathrm{X}_{2}\right)$ had a significant direct effect on competitive advantage $(\mathrm{Y})$, with a significance value of $0.000<0.05$. Thus, it can be concluded that there was a significant

\footnotetext{
${ }^{4}$ Ismail, Perbankan Syariah, (Jakarta: Kencana, 2011) 1st Edition, First Ed, pp. 42-43

${ }^{5}$ Philip Kotler, Gary Amstrong, Prinsip-Prinsip Pemasaran, (Jakarta: Erlangga, 2004) 12 ${ }^{\text {th }}$ Edition, p. 293

${ }^{6}$ Fatati Nuryana, Statistik Bisnis Jilid I (Surabaya: Pena Salsabila, 2013), p. 149
} 
direct effect of service quality $\left(\mathrm{X}_{2}\right)$ on competitive advantage $(\mathrm{Y})$ in which the $\mathrm{R}$ Square reached 0.826 . The summary table showed that the service quality significantly affected competitive advantage by $82.6 \%$. Meanwhile, the rest $(17.4 \%)$ referred to other factors that were not included in this research. It means that service quality had a significant positive effect on competitive advantage in the Sentra Batik Pamekasan. Based on the findings, service quality $\left(\mathrm{X}_{2}\right)$ had a significant direct effect on customer loyalty $(\mathrm{Z})$, with a significance value of $0.062<0.05$. Thus, it can be concluded that there was a significant direct effect of service quality $\left(\mathrm{X}_{2}\right)$ on customer loyalty $(\mathrm{Z})$ in which the $\mathrm{R}$ Square reached 0.616 . The summary table showed that the service quality significantly affected customer loyalty by $61.6 \% \%$. Meanwhile, the rest $(38.4 \%)$ referred to other factors that were not included in this research. It means that service quality has a significant positive effect on customer loyalty in the Sentra Batik Pamekasan. The findings also reported that competitive advantage (Y) had a significant direct effect on customer loyalty $(Z)$, with a significance value of $0.028<0.05$. Thus, it can be concluded that there was a significant direct effect of competitive advantage (Y) on customer loyalty (Z), in which the $\mathrm{R}$ Square reached 0.616 . The summary table showed that competitive advantage significantly affected customer loyalty by $31.6 \%$. Meanwhile, the rest $(38.4 \%)$ referred to other factors that were not included in this research. It means that competitive advantage had a significant positive effect on customer loyalty in the Sentra Batik Pamekasan.

\section{Conclusion}

Based on the research discussion and findings on customer satisfaction, service quality, and competitive advantage towards customer loyalty in Sentra Batik Pamekasan, it can be concluded that: (a). Customer satisfaction $\left(\mathrm{X}_{1}\right)$ had a significant direct effect on competitive advantage $(\mathrm{Y})$, with a significance value of 0.004 $<0.05$. Thus, it can be concluded that there was a significant direct effect of customer satisfaction $\left(\mathrm{X}_{1}\right)$ on competitive advantage (Y) in which the R Square reached 0.826 . The summary table showed that customer satisfaction significantly affected competitive advantage by $82.6 \%$. meanwhile, the rest (17.4\%) referred to other factors that were not included in this research. It means that customer satisfaction had a significant positive effect on competitive advantage in the Sentra Batik Pamekasan. (b). Customer satisfaction $\left(\mathrm{X}_{1}\right)$ had a significant direct effect on customer loyalty $(Z)$, with a significance value of $0.499<0.05$. Thus, it can be concluded that there was a significant direct effect of customer satisfaction $\left(\mathrm{X}_{1}\right)$ on customer loyalty $(\mathrm{Z})$ in which the R Square reached 0.616 . The summary table showed that customer satisfaction significantly affected customer loyalty by $61.6 \% \%$. Meanwhile, the rest $(38.4 \%)$ referred to other factors that were not included in this research. It means that customer satisfaction has a significant positive effect on customer loyalty in the Sentra Batik Pamekasan. (c). Service quality $\left(\mathrm{X}_{2}\right)$ had a significant direct effect on competitive advantage $(\mathrm{Y})$, with a significance value of $0.000<0.05$. Thus, it can be concluded that there was a significant direct effect of service quality $\left(\mathrm{X}_{2}\right)$ on competitive advantage $(\mathrm{Y})$ in which the $\mathrm{R}$ Square reached 0.826 . The summary table showed that the service quality significantly affected competitive advantage by $82.6 \%$. Meanwhile, the rest $(17.4 \%)$ referred to other factors that were not included in this research. It means that service quality had a significant positive effect on competitive advantage in the Sentra Batik Pamekasan. (d). Service quality $\left(\mathrm{X}_{2}\right)$ had a significant direct effect on customer loyalty $(Z)$, with a significance value of $0.062<0.05$. Thus, it can be concluded that there was a significant direct effect of service quality $\left(\mathrm{X}_{2}\right)$ on customer loyalty $(\mathrm{Z})$ in which the R Square reached 0.616 . The summary table showed that the service quality significantly affected customer loyalty by $61.6 \% \%$. Meanwhile, the rest $(38.4 \%)$ referred to other factors that were not included in this research. It means that service quality has a significant positive effect on customer loyalty in the Sentra Batik Pamekasan. (d). Competitive advantage (Y) had a significant direct effect on customer loyalty (Z), with a significance value of $0.028<0.05$. Thus, it can be concluded that there was a significant direct effect of competitive advantage (Y) on customer loyalty $(\mathrm{Z})$, in which the R Square reached 0.616 . The summary table showed that competitive advantage significantly affected customer loyalty by $31.6 \%$. Meanwhile, the rest $(38.4 \%)$ referred to other factors that were not included in this research. It means that competitive advantage had a significant positive effect on customer loyalty in the Sentra Batik Pamekasan.

\section{Reference}

[1] Dharmesta Swastha Basu, Hani Handoko, Manajemen Pemasaran dan Analisis Perilaku Konsumen, Yogyakarta: Penerbit Liberty, 1997.

[2] Engel J.F, R.D Black Well, and P.W. Miniard, Marketing Management, Jakarta: Penerbit Erlangga, 2008.

[3] Ghozali Imam, Aplikasi Analisisis Multivariate dengan Program SPSS Semarang: Badan Penerbit Universitas Diponegoro, 2001.

41 
[4] Hasan Iqbal, Analisis Data Penelitian Dengan Statistik, Jakarta: Bumi Aksara, 2010.

[5] Huda Nurul, Mohammad Heykal, Lembaga Keuangan Islam: Tinjauan Teoritis dan Praktis, Jakarta: KENCANA PRENADA MEDIA GROUP, 2010.

[6] Kotler Philip, Gary Amstrong, Prinsip-Prinsip Pemasaran, Jakarta : Erlangga, 2004.

[7] Kotler Philip, Kevin Lane Keller, Marketing Management, Jakarta: Penerbit Erlangga, 2008.

[8] Kuncoro Mudrajad, Metode Kuantitatif; Teori dan Aplikasi untuk Bisnis \& Ekonomi. Edisi Keempat Yogyakarta: Unit Penerbit dan Percetakan Sekolah Tinggi Ilmu Manajemen YKPN, 2011.

[9] Laksana Fajar, Manajemen Pemasaran; Pendekatan Praktis, Yogyakarta: Graha Ilmu, 2008.

[10] Lupiyoadi Rambat, Manajemen Pemasaran Jasa: Teori dan Praktik, Jakarta: PT. Salemba Emban Patria, 2001.

[11] Martono Nanang, Manajemen Penelitian Kuantitatif, Jakarta: PT.Raja Grafindo Persada, 2011.

[12] Marwanto Aris, Marketing sukses, Yogyakarta: PT. Buku Kita 2015.

[13] Nuryana Fatati, Statistik Bisnis Jilid I, Surabaya: Pena Salsabila, 2013.

[14] Ridwan, Sunarto, Pengantar Statistik Untuk Penelitian, Bandung: Alfabeta, 2009.

[15] Simamora Bilson, Riset Pemasaran, Falsafah, Teori, dan Aplikasi, Jakarta: PT. Gramedia Pustaka Utama, 2004.

[16] Subanti Sri, Arif Rahman Hakim, Ekonometri, Yogyakarta: Graha Ilmu, 2014.

[17] Sugiyono, Metode Penelitian Bisnis, Bandung: Alfabeta, 2012.

[18] Siregar Syofian, Statistika Deskriptif untuk Penelitian, Jakarta: PT Raja Grafindo Persada, 2012.

[19] Suharsaputra Uhar, Metodologi Penelitian Kuantitatif, Kualitatif, dan Tindakan, Bandung: PT Refika Aditama, 2012.

[20] Suharyadi, Purwanto S.K, STATISTIKA: Untuk Ekonomi dan Keuangan Modern, Jakarta: Salemba Empat, 2011.

[21] Supriyanto Sani Ahmad, Masyhur Mahfud, Metodologi Riset Manajemen Sumber Daya Manusia, Malang: UIN Maliki Press, 2010.

[22] Tim Penyusunan Pedoman Karya Ilmiah, Pedoman Penulisan Karya Ilmiah, Pamekasan: STAIN Pamekasan, 2015.

[23] Cahyani Dwi Putri, Tingkat Kepuasan Konsumen Terhadap Kualitas Layanan Perbankan Syariah di Yogyakarta, Jurnal Bisnis dan Manajemen, Volume 6 (2), Oktober 2016.

[24] Danibrata Aulia, Pengaruh Strategi Bersaing Dengan Menggunakan Kualitas dan Kerelasian Pelanggan Terhadap Loyalitas Pelanggan Pada Industri Perbankan, Jurnal Bisnis dan Akuntansi, Vol.15, No.1, Juni 2013.

[25] Haryanto RestyAvita, "Strategi Promosi, Kualitas Produk, Kualitas Layanan Terhadap Kepuasan Pelanggan Pada Restoran MCDONALD'S Manado”,ISSN 2303-1174, Jurnal EMBA Vol. 1 No.4 Desember 2013.

[26] Hasan, Analisis Industri Perbankan Syariah, Jurnal Dinamika Ekonomi Pembangunan, Juli 2011, Volume 1, Nomor 1, Fakultas Ekonomi Universitas Wahid Hasyim Semarang.

[27] HayatiNur, Fatmasaris Sukesti, Peningkatan Loyalitas Konsumen Bank Syariah Melalui Peningkatan Kualitas Layanan dan Kepuasan Dengan Variabel Religiusitas Sebagai Variabel Moderating, Jurnal Economica, Volume VII/Edisi 2/Oktober 2016.

[28] Pritandhari Meyta, Analisis Faktor-Faktor yang Mempengaruhi Loyalitas Pelanggan dan Dampaknya Terhadap Keunggulan Bersaing (studi Pada BMT AMANAH UMMAH SUKOHARJO) jurnal Pendidikan Ekonomi UM Metro Vol.3 No.1 2015

[29] Semuel Hatane, Nadya Wijaya, Service Quality, Perceive Value, Satisfaction, Trust Dan Loyalty, Pada PT. Kereta Api Indonesia Menurut Penilaian Pelanggan Surabaya, Jurnal Manajemen Pemasaran, VOL.4, NO. 1, April 2009.

[30] Sondakh Conny, Kualitas Layanan, Citra Merek dan pengaruhnya terhadap Kepuasan dan Loyalitas Konsumen Tabungan (Studi Pada Konsumen Taplus BNI Cabang Manad0), Jurnal Riset Bisnis dan Manajemen vol.3, No.1,2014, diakses pada, 24 November 2018.

[31] Suryaningtyas Dewi, nuruddin Harahab, Harsuko Riniwati, Analisis Kualitas Pelayanan Karyawan Terhadap Kepuasan Pelanggan (Nelayan), Di UPTD Pangkalan Pendaratan Ikan (PPI) POPOH, Desa Besole Kecamatan Besuki, Tulungangung, Jawa Timur, Jurnal ECSOFIM Vol.1 No.1, 2013.

[32] Tahuman Zainuddin, Analisis Faktor-Faktor Yang Mempengaruhi Loyalitas Pelanggan Serta Dampaknya Terhadap Keunggulan Bersaing, Jurnal Riset Bisnis dan Manajemen Vol.4, No.3, Edisi Khusus Pemasaran \& Keuangan 2016.

[33] Rosda Yusmi Aulia, Analisis Pengaruh Kepercayaan, Komunikasi, Komitmen, dan Penanganan Keluhan Terhadap Loyalitas Konsumen Di PT Bank Negara Indonesia Syariah Kantor Cabang Sudirman Pekanbaru, Skripsi UIN SUSKA RIAU, RIAU, 2015.

[34] Setiawan Rachmawati Yenny, Pengaruh Kepuasan Pelayanan Terhadap Loyalitas Konsumen dan Strategi Untuk Mencapai Keunggulan Bersaing Pada Bank Permata Cabang Yogyakarta, Skripsi Universitas Diponegoro Semarang, 2006.

[35] Sunarto, Analisis Faktor-Faktor Yang Mempengaruhi Loyalitas Pelanggan dan Dampaknya Terhadap Keunggulan Bersaing (Studi Pada Tabungan BRITAMA BRI KANCA KENDAL), Tesis Universitas Diponegoro, Semarang, 2006. 